\title{
El derrotero de Los Libros (1969-1976) y su crítica pedagógica. La interpretación educativa de Antonio Gramsci a través de Christine Buci-Glucksmann
}

\author{
The course of Los Libros (1969-1976) and its pedagogical critic. Educational \\ interpretation of Antonio Gramsci by Christine Buci-Glucksmann
}

Sebastián Gómez

\begin{abstract}
Resumen
El artículo contribuye al abordaje de la recepción pedagógica de Gramsci en Argentina a través del análisis de una revista característica de la nueva izquierda intelectual: Los Libros (1969-1976). Fundamenta que la publicación, en un proceso conflictivo, mantuvo la especificidad de la crítica cultural y pedagógica. Aunque Gramsci resultó evocado en distintas oportunidades, Los Libros, le dedicó una interpretación mediante la traducción de un escrito de C. Buci-Glucksmann. Desde una lectura althusseriana del comunista italiano, su interpretación respondía al proyecto crítico-pedagógico de la publicación.
\end{abstract}

Palabras clave: Los Libros, Gramsci, crítica pedagógica, Althusser; Buci-Glucksmann.

\begin{abstract}
The article contributes to addressing the educational reception of Gramsci in Argentina through the analysis of a feature magazine new intellectual left: Los Libros (1969-1976). Founded that the publication, in a conflictive process, kept the specificity of cultural and educational criticism. Although Gramsci was evoked on several occasions, Los Libros, gave him an interpretation by a written translation of C. Buci-Glucksmann. From a reading of the Italian Communist by Althusser, responding to critical interpretation-education project of the publication.
\end{abstract}

Keywords: Los Libros, Gramsci, pedagogical critic, Althusser, Buci-Glucksmann.

\footnotetext{
* Argentino. Doctor de la Universidad de Buenos Aires en Educación. Mgr. de la Universidad de Buenos Aires en Pedagogías Críticas y Problemáticas socioeducativas. Lic. en Ciencias de la Educación - UBA. Investigador becario del Consejo Nacional de Investigaciones Científicas y Técnicas (CONICET). Correo electrónico: sebastianjorgegomez@gmail.com.
} 


\section{Introducción}

El artículo se inscribe en una tesis doctoral en educación realizada en la Facultad de Filosofía y Letras - Universidad de Buenos Aires (UBA): La recepción y usos de Antonio Gramsci en la nueva izquierda pedagógica y el nacionalismo popular pedagógico (19591976) (Argentina). Contribuye a la indagación de la recepción educativa del comunista italiano a través del análisis de una publicación característica de la nueva izquierda intelectual: Los Libros (LL, 1969 - 1976). Se estructura en dos momentos. Primero: establece una racconto del derrotero de la revista, distinguiendo dos etapas. A diferencia de las perspectivas predominantes que analizan a la publicación en clave de una sobrepolitización ascendente y asfixiante a expensas de una pérdida ejercida sobre lo específico, argumenta que bajo un signo contradictorio y conflictivo, $L L$ persistió en la crítica cultural en su segunda etapa. Segundo: polemiza con una asidua interpretación historiográfica que analiza el itinerario del revolucionario sardo por Argentina y América Latina en términos de oposición a la corriente althusseriana, ahondando la interesante veta sugerida por Starcenbaum ${ }^{1}$.

Aunque categorías gramscianas se emplearon por distintos autores/as a lo largo de la publicación sin ofrecer un tratamiento particular de la obra de Gramsci, en el $\mathrm{n}^{\circ} 32$ (octubre/noviembre de 1973) consagrado al tópico educativo, $L L$ reprodujo un artículo de la filósofa francesa Christine Buci-Glucksmann, "Gramsci y la cuestión escolar". De manera tensa con las claves de lectura del acervo gramsciano sugeridas por su maestro, L. Althusser, C. Buci-Glucksmann ofrecía una renovada exégesis que respondía al doble proyecto crítico educativo de $L L$ : a) elucidar la dominación ideológica del aparato escolar; b) fundamentar una intervención política en la institucionalidad educativa burguesa.

El presente manuscrito expone resultados producidos a través de un enfoque cualitativo, esto es, un enfoque que buscó reconstruir la trama y el sentido del empleo pedagógico de Gramsci en $L L$. De ahí que se desplegaron estrategias y técnicas metodológicas de corte cualitativo para responder a este ejercicio hermenéutico. Concretamente se recolectaron datos mediante la indagación documental, centrándose en $L L$ y el libro de C. Buci Glucksamnn dedicado a la obra de Gramsci ${ }^{2}$. Las revistas culturales de aquellos años, además de expresar zonas conflictivas de intersección entre la actividad editorial y la

\footnotetext{
${ }^{1}$ Marcelo Starcenbaum, (2011), "El marxismo incómodo: Althusser en la experiencia de Pasado y Presente", Izquierdas, $\mathrm{n}^{\circ} 11,2011,35-53$.

En el artículo se refiere al althusserianismo como una tendencia político-filosófica inaugurada por L. Althusser a través de una serie de escritos entrada la década del 60: La revolución teórica de Marx (1965), Para Leer el Capital (1967), La filosofía como arma de la revolución (1968) e "Ideología y aparatos ideológicos de Estado" (1969) que se afincaron en la axiomática global del estructuralismo lévistrasussiano. El althusserianismo conformó una escuela nítida de pensamiento en los 60 de amplía repercusión, que entró en revisión y crisis hacia los años 70. Ver Emilio De Ipola, Althusser, el infinito adiós, Bs. As., Siglo XXI, 2007.

${ }^{2}$ Christine Buci Glucksamnn, Gramsci et l'État (Pour une Théorie Matérialiste de la Philosophie), Paris, Fayard, 1975. Traducido al español, Gramsci y El Estado (Hacia una teoría materialista de la Filosofía), México, Siglo XXI, 1978.
} 
intervención política, se caracterizaron por trazar un círculo para señalar el lugar que ocupaban o aspiraban a ocupar, tomando distancia, de manera más o menos polémica, de otras posiciones. A través de la inclusión de ciertos escritos (como declaraciones, manifiestos, publicidades, etc.) pretendían crear vínculos y solidaridades estables, instaurando un "nosotros" y un "ellos". Trasuntaban, en muchos casos, una estrategia de grupo que se dirimía en una sintaxis, aprehensible no sólo en las declaraciones editoriales sino también en la disposición y contenidos de los textos. El análisis de esta sintaxis de la revista es decisivo para determinar sus contornos ideológicos y estéticos, su política (esto es, el campo de lo deseable y lo posible de cada proyecto) y su geografía (es decir, el espacio de circulación y el espacio imaginario en el que se ubicaba idealmente el proyecto de la publicación) $)^{3}$. Bajo este tratamiento de la fuente documental, el empleo de Gramsci sólo es inteligible al dar cuenta de los propósitos centrales, los antagonismos y las modificaciones de la publicación a lo largo de su existencia. De allí que, como se intentará demostrar, el artículo de C. Buci-Glucksmann ofrecía una interpretación del legado gramsciano inscripto en el proyecto y la demarcación político-teórica de la publicación. Como ya se dijo, también se indago el libro de C. Buci Gluksmann. Es sabido que mientras la fuerza de las revistas culturales reside en la capacidad de cristalizar determinada estrategia susceptible de adecuarse en su devenir y permanecer atenta al signo de la coyuntura, el libro suele conservar una mayor distancia respecto de la inmediatez, colocando el foco en la elaboración de algún tipo de sistema conceptual ${ }^{4}$. En este sentido, el abordaje del libro de la autora busca dar cuenta de los propósitos y nudos conceptuales que atravesaron su artículo, iluminando coincidencias con la estrategia y el proyecto críticopedagógico de $L L$.

En la investigación del itinerario de la obra de autores y autoras, como Gramsci para este caso, es indudable distinguir el campo de origen del de recepción, dando cuenta de los intereses específicos en pugna del último como también de las marcaciones e interpretaciones de los "receptores". Existe un carácter productivo en la lectura y en los usos de la obra de un autor/ $\mathrm{a}^{5}$ que reclama conjugarse con su historicidad. Asimismo no se trata de develar empleos correctos e incorrectos en referencia a una interpretación válida, sino de comprender modalidades y condiciones de posibilidad socio-históricas y sociopolíticas de determinados usos ${ }^{6}$.

\footnotetext{
${ }^{3}$ Beatriz Sarlo, El rol de las revistas culturales, Bs. As., Facultad de Filosofía y Letras Universidad de Buenos Aires, 1992; Adriana Petra, "El momento peninsular. La cultura italiana de posguerra y los intelectuales comunistas argentinos", Izquierdas, $\mathrm{n}^{\circ}$ 8, 2010, 1-25.

${ }^{4}$ Beatriz Sarlo y Carlos Altamirano, Ensayos argentinos. De Sarmiento a la vanguardia, Bs. As, Centro Editor, 1983.

${ }^{5}$ Hans-Robert, Jauss, Pour une esthétique de la réception, París, Gallimard, 1978.

${ }^{6}$ Horacio Tarcus, Marx en la Argentina. Bs. As., Siglo XXI, 2007, 20-21.
} 


\section{El periplo de Los Libros (1969-1976). La permanencia de la crítica cultural}

$L L$ fue una publicación característica de la nueva izquierda intelectual en Argentina hacia fines de los años 60 y principios de los 70 . El primer número apareció en cercanía al Cordobazo, julio de 1969, y el último, el n 44, en enero-febrero de $1976^{7}$. Durante su periplo estuvo atravesada por dos procesos característicos de los años 60/70: la modernización cultural y la radicalización política. En otras palabras, $L L$ se dirimió entre un discurso especializado y una pretendida intervención política desde su propia esfera de competencia.

Héctor "Toto" Schmucler que en 1968 había vuelto a la Argentina luego de estudiar en Francia con Roland Barthes promovió el proyecto de $L L$ y lo dirigió en soledad hasta el $n^{\circ}$ 23 (noviembre de 1971), cuando se conformó un Consejo de Redacción. La revista asumió como modelo de referencia la publicación francesa La Quinzaine Littéraire (fundada en 1966 por Maurice Nadeau y François Erva). Como ésta, su propuesta original residía en intervenir mensualmente en el mercado editorial reseñando libros de distintas áreas: literatura, antropología, comunicación, psicoanálisis, filosofía, pedagogía. En sus inicios, el libro fue el formato predilecto constituyéndose como el objeto decisivo. Se pretendía divulgar conceptualizaciones que hasta entonces eran patrimonio de grupos restringidos de expertos, y desacralizar así la impronta burguesa de la literatura. La revista era vendida en quioscos, lo cual insinuaba su ansia de popularización, sin por ello perder agudeza crítica.

El primer subtítulo es indicativo del proyecto original de $L L$ : "Un mes de publicaciones en Argentina y el mundo". La publicación estaba animada por objetivos modernizadores: poner al día, actualizar, los saberes producidos en las distintas áreas de conocimiento y, con ello, dar a conocer nuevas corrientes de pensamiento como la antropología estructural, el psicoanálisis lacaniano o el marxismo althusseriano. La nota editorial del primer número, con el título "La creación de un espacio", ilustraba los propósitos de $L L$ y sus aires modernizadores. En principio, buscaba llenar un vacío, sin reconocer antecedentes, ni

\footnotetext{
${ }^{7}$ Existen una serie de trabajos que han abordado el recorrido de $L L$. En ellos, en general, se ha puesto el eje en el tratamiento de la cuestión literaria, pero la faceta pedagógica y los usos de Gramsci en la publicación han sido inexplorados. Entre los trabajos sobre $L L$ se encuentran:

Jorge, Panesi, "La crítica argentina y el discurso de la dependencia", Panesi, J. Críticas. Bs. As., Norma, 2000 [1985], 17-48; Eva Fontdevila y Adrián Pulleiro, "Los Libros. De la modernización a la partidización", Revista Zigurat, n`5, 2004, 168-173; AA.VV, "Los Libros: la construcción de un texto posible, entre el Cordobazo y el Golpe". El Matadero. Revista crítica de literatura argentina, $\mathrm{n}^{\circ}$ 4, 2005, 241-260; José Luis De Diego, ¿Quién de nosotros escribirá el Facundo? Intelectuales y escritores en Argentina (1970 - 1986), La Plata, Al Margen, 2007; Anna Popovitch, "La recepción de Althusser por la Nueva Izquierda Argentina: el caso de Los libros (1969-1976)". Granados García, A. (coord.), Las revistas en la historia intelectual de América Latina. México, Universidad Autónoma Metropolitana / J. Pablos, 2012, 127-143; Patricia Somoza y Elena Vinelli, "Para una historia de Los Libros", Los Libros: edición facsimilar. Bs. As., Biblioteca nacional, 2011, 9-19; Adrián Celentano, "Insurrección obrera y compromiso intelectual", Archivos de historia del movimiento obrero y la izquierda, $\mathrm{n}^{\circ} 4,2014,53-76$.
} 
parentescos. Como en otras franjas de la nueva intelectualidad de la década del 60, se abría camino sin recurrir a maestros ${ }^{8}$.

El proyecto era radicalmente nuevo y estaba signado por la exclusión académica de sus actores. El vacío divisado no se relacionaba sólo con una vacancia en el mercado editorial sino también con las características de una universidad intervenida por los sectores más conservadores. Como es sabido, los efectos de la "Revolución Argentina" (1966-1973) no fueron uniformes en las universidades, pero la Facultad de Filosofía y Letras de la UBA se vio particularmente afectada. Una revista como la mentada por H. Schmucler, editada en Buenos Aires, no encontraba, para sus animadores, eco alguno en la facultad intervenida, reacia a las nuevas tendencias intelectuales. Así los parámetros de legitimación de la actividad intelectual transcurrían entre pares y en contraposición con sus "mayores". La revista tampoco era la expresión de alguna organización política. En suma, $L L$ se vio compelida a construir su propio anclaje institucional. El apoyo inaugural de la editorial Galerna y de Guillermo Schavelzon (que apareció como editor responsable), resultó vital.

Ahora bien, si existía un vacío, ¿en qué consistía ese espacio a ocupar? ¿Cuáles eran los límites de este nuevo espacio? La expresión francesa nouvelle critique -nueva críticadeterminaba los parámetros. Novedad y crítica, modernización cultural y radicalización política, se anudaban en el proyecto original: "Se trata pues, de crear un espacio que en el caso de Los Libros tiene un terreno preciso: la crítica, darle un objeto -definirla- y establecer los instrumentos de su realización permitirán dibujar la materialidad con la que se pretende llenar el 'vacío' de la recordada expresión de circunstancia"9.

Dos aspectos resaltan aquí ${ }^{10}$. Por un lado, la crítica no se definía como una práctica sino como un "espacio", un "terreno". Las huellas del influyente estructuralismo se advertían en el proyecto original. Como en otras franjas de la nueva intelectualidad durante los años 60, el faro político intelectual se corría de J. P. Sartre para afincarse en el estructuralismo. Por otro lado, la crítica no se adjetivaba. Ni crítica literaria, ni crítica política, ni crítica social. Crítica "a secas". También aquí, sobrevolaban las marcas del estructuralismo. R. Barthes ya había proclamado la intransitividad de la escritura, su innecesario complemento. A través de la crítica del libro se cuestionaba y abordaba el pensamiento en su conjunto. Y en este pasaje, la ideología, en tanto objeto de la crítica, operaba como mediación. Se consideraba que en todo discurso existía un nivel de significación que era preciso y posible desentrañar. Al permanecer el lenguaje cargado de ideología, el objetivo se ampliaba a la "totalidad del pensamiento" y no se resumía al lenguaje literario.

Si bien es improcedente reducir la influencia en este aspecto al legado althusseriano, su ascendencia resultaba más que evidente. Recuérdese que el filósofo francés había definido la ideología, en una sociedad clasista, como una falsa conciencia. Toda ideología que explicitaba, también enmascaraba. Lejos de suministrar a los hombres el conocimiento objetivo del sistema social, daba pie a una representación mistificada y deformante. La

\footnotetext{
${ }^{8}$ Oscar Terán, Nuestros años sesentas. La formación de la nueva izquierda intelectual en la Argentina, 19561966, Bs. As., Puntosur, 1991, 97.

9 "Editorial", Los Libros, n 1, julio de 1969, 3.

${ }^{10}$ De Diego, op. cit, 24.
} 
nueva crítica estaba destinada a desenmascarar, a interrogar las ideas. El enemigo de esta tentativa no era otro que el realismo. Los nuevos instrumentos liberaban al crítico de la lectura ingenua. Se debía trabajar y desmenuzar, bajo la certeza de contar con los medios adecuados, al propio texto, a su realismo. También aquí soplaban los aires de un proyecto modernizador $^{11}$ que se conjugó con el sitio asignado al trabajo intelectual por parte del proyecto althusseriano $^{12}$. La práctica teórica de una ciencia reclamaba cierta autonomía de la práctica política, trabajaba con los "hechos" ideológicos elaborados por la práctica teórico-ideológica anterior, a la que sometía a crítica, y contribuía decididamente a la lucha de clases al ofrecer un conocimiento objetivo de las leyes de la dinámica social. En $L L$, al igual que en L. Althusser, el trabajo teórico se jerarquizaba $\mathrm{y}$, paulatinamente, la publicación le asignó, como el filósofo francés, un lugar específico en la conflictiva escena política y en la tarea de someter a crítica los desarrollos teóricos e ideológicos circundantes. La escisión althusseriana entre ciencia e ideología aparecía como fundamento de esta tentativa.

Existen hilos de continuidad a lo largo del trayecto de $L L$, pero es posible divisar dos etapas, siendo el $\mathrm{n}^{\circ} 29$ (marzo-abril de 1973) el momento divisorio. En su recorrido, la unidad entre modernización y radicalización persistió, aunque tuvo énfasis distintos. La primera etapa es identificable por la presencia de H. Schmucler en la dirección, el formato tabloide y por el rasgo sobresaliente de una revista crítica de libros que se fue extendiendo progresivamente hacia otros objetos culturales y procesos políticos latinoamericanos. La segunda etapa, marcada por la dirección de Carlos Altamirano, Ricardo Piglia y Beatriz Sarlo, así como por el desplazamiento de H. Schmucler, se caracterizó por una mayor extensión y menor cantidad de artículos. Además de operar una mudanza del interés inicial por los procesos regionales a la confrontación entre China y la URSS, la Revolución China y la divulgación de textos de Mao Tse-Tung, se habilitó la inclusión de análisis de la coyuntura y, por tanto, exigió una mayor precisión política. También implicó cambios estéticos: se abandonó el formato tabloide por uno reducido $\mathrm{y}$, tendencialmente, desaparecieron las ilustraciones en la tapa, que fueron reemplazadas por los títulos de las notas centrales. Por último, la frecuencia: pasó de una publicación mensual a rodar cada dos meses.

Aunque el $\mathrm{n}^{\circ} 29$ resultó decisivo, la publicación estuvo atravesada por diversos puntos de inflexión. Uno de ellos acaeció en el $\mathrm{n}^{\circ}$ 8, mayo de 1970. La nota editorial, titulada "etapa", era la segunda editorialización de la publicación (luego del número inicial) e introducía novedades. En primer término, un nuevo anclaje: América Latina. Reconocidas editoriales latinoamericanas comenzaban a auspiciar la publicación. La mentada "latinoamericanización", como aseguraba el editorial, respondía, fundamentalmente, a demandas financieras. La proyectada difusión, por otra parte, se alcanzó en escasa medida. La cantidad de ejemplares aumentó, promediando una tirada de 5.000, y su distribución alcanzó gran parte de Latinoamérica, pero el destino del consumo no varió: la mayor parte

\footnotetext{
${ }^{11}$ Panesi, op. cit, 24.

${ }^{12}$ Popovitch, op. cit, 132
} 
de las ventas siguieron realizándose en Argentina $^{13}$. De todas maneras, la cuestión latinoamericana y la problemática de la dependencia animaron su ejercicio crítico. La innovación fundamentó el nuevo subtítulo de la revista. El lugar del mundo lo ocupaba, ahora, la región: "Un mes de publicaciones en Argentina y América Latina". Además el editorial auguraba cambios más profundos:

También se innovará en otros aspectos. Ya se sabe que el formato libro no privilegia ninguna escritura. Es posible que las obras más importantes se estén escribiendo en las noticias periodísticas o en los flashes televisivos. O en los muros de cualquier parte del mundo. Estos textos, al igual que los libros tradicionales, requieren una lectura que descubra su verdad. Los Libros se ocupará, pues, cuando sea necesario, de los diarios, la televisión, el teatro, la radio, el cine ${ }^{14}$.

Como se verá, a los artículos de crítica literaria la revista le comenzará a añadir otros ligados a temáticas estrictamente políticas (a partir del $\mathrm{n}^{\circ} 15-16$, enero-febrero de 1971). No obstante, entre ambas esferas, hubo una serie de textos que ocuparon una posición intermedia: se trataba de ensayos de crítica cultural, esto es, análisis de objetos de la cultura de masas ${ }^{15}$. En rigor, el editorial $\mathrm{n}^{\circ} 8$ abrió la mirada hacia nuevos objetos que ya estaban siendo tematizados aunque, es cierto, de una manera marginal: en el $n^{\circ} 1$ hubo un ensayo sobre los graffitti ${ }^{16}$ mientras en el $\mathrm{n}^{\circ} 2 \mathrm{y} \mathrm{n}^{\circ} 7$ se abordó el cine ${ }^{17}$. A partir del $\mathrm{n}^{\circ} 8$ existió una mayor consideración sobre estos objetos aledaños, una suerte de "extensión de las fronteras" ". Así, en el curso de la publicación se registró una prolífica producción sobre distintos objetos culturales como el cine $^{19}$, la televisión ${ }^{20}$, las historietas ${ }^{21}$, etc. $L L$ los abordó bajo el proyecto crítico original: cuestionar su realismo. Y, nuevamente, la ideología aparecía como instancia mediadora. Se trataba de dar cuenta de la dinámica y de los mecanismos ideológicos de los aparatos o instituciones culturales que producían los objetos populares.

\footnotetext{
${ }^{13}$ Somoza y Vinelli, op.cit, 11.

14 “Editorial", Los Libros, n 8, mayo de 1970, 3.

${ }^{15}$ Peller, op. cit, 13.

${ }^{16}$ Eduardo Gudiño Kieffer, “Graffiti”, Los Libros, n 1, julio de 1969, 26.

${ }^{17}$ Edgardo Cozarinsky, "Escritura y cine: dos tiempo verbales", Los Libros, n 2, agosto de 1969, 13; Pier Paolo Pasolini, “Teorema”, Los Libros, n 7, enero de 1970, 6-9.

${ }^{18}$ Panesi, op. cit, 24.

${ }^{19}$ Entre otros, Máximo Soto, "San Martín, mito y consumo”, Los Libros, n 8, mayo de 1970, 24-25; Juan Carlos Brasi, "La captación de una ausencia: a propósito de "pequeños asesinatos", Los Libros, $\mathrm{n}^{\circ} 27, \mathrm{julio}$ de 1972, 24-25; Beatriz Sarlo, “Cine argentino. De Juan Moreira a La Tregua”, Los Libros, n 39, enero-febrero de 1975, 11-14; Beatriz Sarlo, "Sobre Nazareno Cruz y el lobo”, Los Libros, n 41, mayo-junio de 1975, 2425.

${ }^{20}$ Entre otros, Beatriz Sarlo, "Los canales del Gran acuerdo”, Los Libros, n ${ }^{\circ} 27$, julio de 1972, 3-7; Beatriz Sarlo, "Elecciones: cuando la televisión es escenario", Los Libros, n 29, marzo-abril de 1973, 4-10.

${ }^{21}$ Por ejemplo, Oscar Steimberg, "El lugar de Mafalda", Los Libros, n 17, marzo de 1971, 6-7.
} 
También sobrevolaban las huellas althusserianas en este desplazamiento del objeto. La propuesta de L. Althusser elaborada en el famoso ensayo "Ideología y aparatos ideológicos de Estado", fundamentaba un análisis ideológico de las instituciones culturales. Trataba los fenómenos culturales como prácticas simbólicas ancladas en aparatos atravesados por tensiones ideológicas ${ }^{22}$. La ideología continuaba operando como instancia analítica mediadora en $L L$, pero ya el centro no era el abordaje intratextual o la mediación libresca, sino su anclaje institucional. Desde luego, el antagonismo social no se subsumía al ámbito ideológico, pero la publicación registraba este espacio como un lugar privilegiado de la disputa a su alcance. Como se verá, el aparato escolar resultará un objeto privilegiado en esta reflexión. A su vez, la revelación de estos mecanismos de producción social de la ideología se ligaba con la intervención política. La revista se proponía desmenuzar y evidenciar la dominación, la dependencia cultural, para abrir, de este modo, brechas posibles de intervención en el terreno político-cultural. La crítica devenía prospectiva ${ }^{23}$. Sintéticamente, esta faceta crítica en $L L$ se estructuraba en dos momentos. Primero, al emplear la noción de crisis abría aquello que el análisis de la dominación ideológica clausuraba: las brechas al interior de la rutina institucional. Segundo, sugería los caminos prácticos de intervención.

Otro punto de inflexión en el periplo de $L L$ lo constituyó el $\mathrm{n}^{\circ} 15-16$, enero-febrero de 1971 ("un número doble especial”, decía su tapa), cuando comenzó el análisis de los procesos políticos latinoamericanos. La publicación se comprometía con la radicalización política en curso. Chile, el segundo faro político latinoamericano -luego de Cuba- para la intelectualidad crítica de entonces, inauguró este nuevo momento. Números siguientes se dedicaron a otros países de la región. De todos modos el proyecto crítico original permaneció. El editorial $\mathrm{n}^{\mathrm{o}} 21$ (agosto de 1971) al tiempo que anunciaba el autofinanciamiento de $L L$-ante la desvinculación de Galerna y la pérdida de auspicio de importantes editoriales de Latinoamérica-, reafirmaba la necesidad de abordar también "esos otros textos que constituyen los hechos históricos sociales" a través de decodificar "el mundo ideológico en que se insertan" ${ }^{24}$. Además, el editorial sugería un cambio que estaba por llegar en la publicación. Otra vez las metáforas estructuralistas. Se trataba de un constituir... un espacio. ¿Cuál era la renovada ocupación? "Una crítica política de la cultura", como sugería el editorial. El n 22 (septiembre de 1971) cristalizó el cambio a través de un nuevo subtítulo para la publicación: "Para una crítica política de la cultura".

A estas innovaciones le siguieron otras. Desde el $\mathrm{n}^{\circ} 23$ (noviembre de 1971), por razones financieras, dejó de imprimirse en color. El blanco y negro la acompañará hasta su ocaso. En este número se introdujo otra modificación: apareció un Consejo de Dirección, integrado por H. Schmucler - que prosiguió, a su vez, como "Director responsable"-, Carlos Altamirano y Ricardo Piglia -ambos de filiación maoísta-. La razón principal de esta innovación reposaba en la voluntad pasajera del director de imprimirle una impronta maoísta a la revista. Como recuerda, R. Piglia: "Toto Schmucler se vuelve maoísta por

\footnotetext{
22 Popovitch, op. cit, 140.

23 AA.VV., op. cit, 248.

24 "Editorial", Los Libros, n 21, agosto de 1971, 3.
} 
quince días más o menos (risas). En esos quince días, como yo también era maoísta, decidimos darle esa orientación a la revista. Y entonces yo digo: 'invitémoslo a Altamirano', que también era maoísta"25.

Pero la posición política del director fue efímera. Al igual que sus excompañeros de ruta, los impulsores de Pasado y Presente, H. Schmucler comenzó a simpatizar con el ala combativa del peronismo. Entonces volvió sobre su jugada: amplió el Consejo de Dirección, recientemente creado. En el nº 25 (marzo de 1972) sumó a Beatriz Sarlo, por entonces adherente al peronismo, a Germán García -su amigo y renuente a asumir posición política alguna- y a su compañera, Miriam Chorne. Pero el nuevo esquema no resolvió los desequilibrios políticos divisados por H. Schmucler: B. Sarlo, al poco tiempo, se pasó del peronismo al maoísmo, específicamente al Partido Comunista Revolucionario (PCR, que surgió en 1968); G. García se desentendía de la querella política en la revista; M. Chorne no asumió una actitud beligerante a la altura de los/as otros/as miembros. La relación de fuerzas al interior de $L L$ no era favorable para su fundador.

El $n^{\circ} 27$ (julio de 1972) destinado a abordar el Gran Acuerdo Nacional (GAN) fue un decisivo punto de ruptura. C. Altamirano había sido designado como responsable para escribir un artículo introductorio sobre el asunto. La posición política del autor estaba lejos de H. Schmucler, quien no avalaba la inclusión de un artículo tan crítico del peronismo. El director de la revista preparó otro, pero fue rechazado por el "ala maoísta" que apoyaba tanto la posición de C. Altamirano como la publicación del artículo (que, finalmente, salió en el $\mathrm{n}^{\circ} 27^{26}$ ). Aunque el $\mathrm{n}^{\circ} 28$ (septiembre de 1972) intentó retomar el proyecto original, las tensiones eran elocuentes. El n 29 (marzo-abril de 1973) cristalizó el alejamiento de $\mathrm{H}$. Schmucler, G. García y M. Chorne. El ala maoísta pasó a ocupar el centro de la revista: C. Altamirano, B. Sarlo (ambos del PCR) y R. Piglia (de Vanguardia Comunista - VC-. agrupamiento aparecido en 1965). El PCR y VC constituían las agrupaciones maoístas más importantes en Argentina por entonces.

Es frecuente afirmar que la nueva conducción de $L L$ implicó la acentuación de su politización y, por tanto, una pérdida del proyecto original ${ }^{27}$. Se suele suponer que esta politización fue en ascenso hasta que disgregó las razones iniciales. Sin dudas, la nueva dirección maoísta introdujo modificaciones (ya apuntadas) que significaron una nueva etapa para $L L$, pero se estima desacertado sostener que esta politización resolvió la tensión entre modernización y radicalización "a expensas de una pérdida o de una represión ejercida sobre lo específico"28. Aquí se reedita, una vez más, la concepción de los años 70 en clave de una sobrepolitización, incapaz de atender a las especificidades. Aplicado a $L L$ : la crítica cultural se habría subsumido a la política, ergo, se disgregaron los propósitos

\footnotetext{
${ }^{25}$ Entrevistado por Somoza y Vinelli, op. cit, 15. No deja de llamar la atención que el recuerdo de una convergencia política se simplifique a un episodio meramente contingente y se solape con la risa, en una suerte de ridiculización del derrotero de la publicación. Tal vez el afán de abjurar de este pasado teórico, sea una de la causas de la forma que asume el recuerdo.

${ }^{26}$ Carlos Altamirano, "El Gran Acuerdo Nacional", Los Libros, n² 27, julio de 1972, 10-13.

${ }^{27}$ Fontdevila y Pulleiro, op. cit, 18.

${ }^{28}$ Panesi, op. cit, 29.
} 
iniciales. La politización se los llevó consigo. Sin embargo es posible afirmar que su proyecto de crítica cultural no fue abandonado. La propia editorial del $n^{\circ} 29$ reafirmó la orientación de los años previos. El objeto fundamental de análisis proseguía: la ideología y su enraizamiento en las prácticas culturales de las instituciones. Y el proyecto también: "Se trataría de descifrar -elaborando al mismo tiempo los métodos y los instrumentos de análisis- las 'formaciones' ideológicas como dimensión específica de la política de las clases sociales y cuya eficacia, si bien subordinada, es real" 29 .

La aspiración del editorial abarcó al conjunto de la segunda etapa de la revista. Lejos de una pérdida sobre lo específico, $L L$ continuó con su análisis sobre los mecanismos y dinámicas de los aparatos culturales. Si la cuestión pedagógica había sido tematizada hasta el momento, su profundización y abordaje ocurrirá, tal y como se verá, en su segunda etapa. Varias de las esferas culturales contempladas en el primer ciclo vital de $L L$ continuaron: además de la pedagogía, los análisis sobre la salud mental ${ }^{30}$, el problema de la urbanización en las ciudades de Buenos Aires y Rosario ${ }^{31}$, el folklore y la cultura popular ${ }^{32}$, la antropología y el imperialismo ${ }^{33}$, etc. Indicativo de la permanencia del proyecto, se conservó la estructura de la publicación, la que incluía su característica sección dedicada a libros de reciente publicación (con algunos brevísimos comentarios) en sus últimas páginas.

Es incuestionable que, en su tramo final, la discrepancia política y la influencia de los partidos marcaron a la revista. De hecho, aunque se redujo la publicidad, aparecieron nuevos anuncios vinculados a publicaciones del PCR y VC, y la última crisis de $L L$ provino de una discordancia política al interior del arco maoísta explicitada en el $\mathrm{n}^{\circ} 40$ (marzo-abril de 1975) sobre la caracterización del gobierno de Isabel Perón. Pero la evolución estuvo lejos de la linealidad ${ }^{34}$. El proyecto, de nítida presencia althusseriana, de establecer una relación orgánica, aunque al mismo tiempo autónoma entre el compromiso político y la producción intelectual, entre la práctica teórica y la praxis política, no claudicó linealmente, sino que, aun con sus tensiones y modificaciones, persistió en la segunda etapa de la revista.

El 44 (enero-febrero de 1976) fue el último número de $L L$. La irrupción del golpe cívico-militar en marzo de 1976 significó la clausura y allanamiento de la publicación. El $\mathrm{n}^{\circ} 45$ quedó definitivamente perdido. Como otras expresiones de radicalización de los años 70, la tragedia tocó a su puerta con el golpe cívico-militar.

\footnotetext{
29 "Editorial", Los Libros, n 29, marzo-abril de 1973, 3.

${ }^{30} \mathrm{El} \mathrm{n}^{\circ} 34$ (marzo-abril de 1974) fue dedicado exclusivamente a este tema. También, en el $\mathrm{n}^{\circ} 38$ (noviembrediciembre de 1974) contuvo artículos al respecto. El asunto se retomó en el n 40 (mayo-junio de 1975) que además de un artículo, le consagró parte de la portada.

${ }^{31}$ El n 36 (julio-agosto de 1974) llevó como título: "La urbanización dependiente: Buenos Aires / Rosario". La mayoría de los artículos abordaron el asunto.

${ }^{32}$ El n 39 (enero-febrero de 1975) le destinó un artículo al tema. También allí se abarcó el cine argentino, el uso y producción de anfetamina y la dependencia tecnológica en América Latina.

${ }^{33} \mathrm{El} \mathrm{n}^{\circ} 43$ (septiembre-octubre de 1975) desarrolló esa temática.

34 Celentano, op.cit, 71.
} 


\section{El proyecto crítico-pedagógico de $L L$}

La cuestión pedagógica resultó un tema frecuente. $L L$ se ocupó del asunto en al menos siete niveles: a) reseñas extensas sobre libros recientemente publicados ${ }^{35}$; b) artículos que tenían como objeto la obra de un escritor o corriente pedagógica o bien de autores cuyas consideraciones impactaron en el terreno pedagógico ${ }^{36}$; c) artículos que reflexionaron sobre el papel y funcionamiento de la institución educativa -escolar o universitaria- ${ }^{37}$; d) artículos que inscribieron el sistema educativo local en los problemas de la dependencia política y económica del país. Si bien la teoría y el problema de la dependencia tiñó a varias de las reflexiones pedagógicas en $L L$, hubo algunos casos paradigmáticos ${ }^{38}$; e) artículos políticos o reproducción de documentos de colectivos destinados a analizar la situación del movimiento universitario o bien de dar cuenta de experiencias político-pedagógicas ${ }^{39}$; f) el abordaje de los procesos políticos en países latinoamericanos incluyó, en casi todos los casos, reflexiones sobre el plano pedagógico; g) los brevísimos comentarios que aparecían en el catálogo de "libros publicados" en las últimas páginas de la revista a fin de actualizar la bibliografía al lector/a. En esta parte de la publicación, la sección pedagogía denominada más tarde educación- estuvo desde un principio y se conservó en casi todos los números.

Más allá de estos niveles, el tratamiento del tópico pedagógico permaneció, predominantemente, bajo el proyecto de la nueva crítica. Por un lado, se actualizaban y comentaban las novedades en el área. Por el otro, la crítica educativa contenía dos ejes: develar los mecanismos de funcionamiento del aparato escolar, en particular, su impronta ideológica y, a partir de ello, estructurar una crítica prospectiva. Se trataba de situar el sistema educativo en las conflictivas relaciones de fuerzas. Ambos ejes animaron los números consagrados al tema pedagógico: el $\mathrm{n}^{\circ} 31$, agosto-septiembre de 1973 , y el n 32 ,

\footnotetext{
${ }^{35}$ Ya en el n 1, Juan Carlos Torre, “Estudiantes: nueva oposición”, Los Libros, n 1, julio de 1969, 22-3; en el $\mathrm{n}^{\circ}$, cuando apareció por primera vez la sección Pedagogía, Diana Marzoratti, "La escuela y el mundo de trabajo", Los Libros, n ${ }^{\circ}$ 7, enero-febrero de 1970, 28; S/autor/a, "Paulo Freire: pedagogía del oprimido", n 17, marzo de 1971, 28-30.

${ }^{36}$ Por ejemplo, Rafael Urzain, "Frantz Fanon: Alienación y violencia más allá del tercer mundo", Los Libros, $\mathrm{n}^{\circ} 13$, noviembre de 1970, 24-25.

${ }^{37}$ Justa Ezpeleta, Marta Teobaldo y Guiller Villanueva "Educación, ideología y control social". Los Libros, ${ }^{\circ}$ 13, noviembre de 1970, 18-22; Carlos Altamirano, "Universidad: cultura y dependencia", Los Libros, n 23, noviembre de 1971, 5-6; Juan Carlos Tedesco, "Educación y política en América Latina", Los Libros, n 40, marzo-abril de 1974, 11-16.

${ }^{38}$ Fernando Mateo, “La enseñanza técnica en Argentina”, Los Libros, n 43, septiembre-octubre 1975, 19-20.

39 Ramón Cuevas y Osvaldo Reisz (seudónimos de Antonio Marimón y Horacio Crespo dos jóvenes intelectuales alineados al PCR), "El movimiento estudiantil: de la Reforma al Cordobazo", Los Libros, $\mathrm{n}^{\circ} 21$, agosto de 1971, 17-19; Adrián Caballero, "Facultad de Arquitectura de Rosario: balance de seis meses de lucha", Los Libros, n 23, noviembre de 1971, 11-13; S/autores/as, "Chile: La Reforma Universitaria en la Universidad de Concepción”, Los Libros, n 23, noviembre de 1971, 14-17; Agrupación docente 29 de Mayo de la Facultad de Filosofía y Letras de la UBA, "Frente a una historia que no es la nuestra", n 24, enero de 1972, 20-23; Jorge Togneri, "Facultad de Arquitectura de La Plata: una experiencia”, n 24, enero de 1972, 24-26.
} 
octubre-noviembre de 1973, titulados respectivamente "Argentina: educación e ideología" y "Educación en Argentina (II)". Aparecieron en el marco del proceso de movilización y organización sindical que culminó en la fundación de la Confederación de Trabajadores de la Educación de la República Argentina (CTERA). Con ellos, $L L$ pretendió tanto evidenciar la dominación ideológica ${ }^{40}$, como ponderar las disputas y posibilidades en el aparato escolar $^{41}$, por ejemplo, a través de la reproducción de documentos de sindicatos docentes ${ }^{42}$. Con todo, al $\mathrm{n}^{\circ} 31$, consagrado a desmenuzar los mecanismos ideológicos dominantes del aparato escolar, le prosiguió el $\mathrm{n}^{\circ} 32$, más atento a la elaboración de propuestas o a la intervención político-pedagógica.

La iniciativa crítica inicial de $L L$, esto es, su afán revelador de la ideología intratextual, expresado nítidamente en el terreno de la literatura, abarcó también al ámbito educativo. En la materialidad escolar, donde la ideología se arraigaba y producía sus efectos deformantes, los manuales escolares resultaron un objeto privilegiado de estudio. Así, por ejemplo, J. Delgado, C. Martínez y J. Schwartzman, en el n 38 de $L L$ (noviembre-diciembre de 1974), analizaron los manuales de literatura de la escuela secundaria en Argentina, para evidenciar su funcionalidad enmascaradora y los desplazamientos de otras manifestaciones literarias ${ }^{43}$. Los/as autores/as refirieron a Gramsci, concretamente a una cita del libro Los intelectuales y la organización de la cultura ${ }^{44}$. La literatura escolar replicaba la distinción de diversos grados en la actividad intelectual observada por el comunista italiano. En la cúspide, los creadores de las diversas ciencias, de la filosofía, del arte; en la parte inferior, los más humildes administradores y divulgadores de la riqueza intelectual ya existente. Anclados/as, en sintonía con L Althusser, en la crítica a la materialidad del dominio ideológico, asumían esta observación gramsciana para analizar la institución educativa, específicamente, a través de los manuales escolares.

Al igual que en el periplo de $L L$, los textos no fueron los únicos objetos. Se contemplaron otros bajo el mismo proyecto crítico. Es decir, el análisis de los textos escolares estuvo acompañado por otros objetos del espacio educativo pero siempre bajo la

\footnotetext{
${ }^{40}$ Del $n^{\circ}$ 31: Horacio Cuello y Fernando Mateo, "Un discurso ideológico transaccional: los objetivos de la política educacional de la 'Revolución Argentina'", Los Libros, agosto-septiembre de 1973, 13-19; Juan Carlos Tedesco, "Educación e ideología en Argentina. Notas para una investigación”, Ibid, 4-12.

${ }^{41}$ Reina Cheja y Beatriz Grego, "Apuntes para una teoría de la inserción en el proceso educativo", Los Libros, $\mathrm{n}^{\circ}$ 31, agosto-septiembre de 1973, 24-27. Con un evidente filón althusseriano condensado en la noción de problemática y el trabajo teórico, proponían intervenciones prácticas fundamentadas en conocimientos científicos. Otras artículos que señalaban los quiebres en el sistema educativo en el $\mathrm{n}^{\circ} 32$, fueron: Horacio Cuello y Fernando Mateo, "Crisis ideológica y sindicalización: el magisterio del Gran Buenos Aires", Ibid, 10-17; Leandro Leiva, “Argentina 1973: Movimiento docente", Ibid, 18-20; Horacio Cuello y Fernando Mateo, "Algunos datos cronológicos acerca del proceso de sindicalización de la docente (1971-1973)", Ibid, 24-26.

${ }^{42}$ S/autores/as. "Declaración del Congreso de la Central Única de Trabajadores de la Educación de la República Argentina y de la Agrupación 18 de noviembre”, Los Libros, n 32, octubre-noviembre de 1973, 21-23.

43 Josefina Delgado, Carlos Martínez, Julio Schwartzman "La enseñanza en los textos de la escuela secundaria", Los Libros, $\mathrm{n}^{\circ}$ 38, noviembre-diciembre de 1974, 8-15.

${ }^{4}$ Ibid, 11.
} 
perspectiva de elucidar la dominación ideológica en su seno. En definitiva, se trataba de leer no sólo los textos escolares sino también el aparato ideológico escolar como un texto a develar. En esta empresa la ideología fue la instancia mediadora privilegiada.

El tratamiento de la cuestión educativa supuso su delimitación respecto de corrientes pedagógicas del período. Un blanco recurrente fue P. Freire, tan en boga por entonces, y apropiado, en el plano local, por el nacionalismo popular pedagógico. $L L$ abordaba en dos claves las obras de P. Freire: en una clave modernizadora y otra radicalizada. Por un lado, daba cuenta de las apariciones de sus libros. Por otro, lo sometía a severos cuestionamientos. El editorial $n^{\circ} 21$ (agosto de 1971) explicitaba un criterio que no siempre fue respetado. Allí se decía: "Más de una vez, numerosos temas dejaron de considerarse en las páginas de la revista porque no se encontró la persona adecuada para un adecuado tratamiento. Por otra parte, nos negamos sistemáticamente a repetir comentarios meramente descriptivos o valoraciones cargadas de adjetivos" $"$.

Aplicable a los artículos, los breves comentarios que en algunos casos acompañaban a los libros recientemente publicados en la última sección, desmentían esta preocupación por no desembocar en "valoraciones cargadas de adjetivos". Si bien eran comentarios al paso que no despertaban mayor interés -ni siquiera había firma-, estaban signados por un abandono del rigor de la escritura crítica y caían en descalificaciones contra escritores de quienes la revista se diferenciaba ostensiblemente ${ }^{46}$. En el apartado sobre los libros distribuidos del no 33 (enero-febrero de 1974) se incluyó una obra de P. Freire ¿Extensión o comunicación? La concientización del medio rural, acompañado de un brevísimo comentario que introducía una afirmación autocrítica del autor: "Paulo Freire, en las palabras que abren el volumen, dice haber preferido 'mantenerlo casi como lo escribí, con sus omisiones y sus puntos ingenuos"”. Los postulados freirianos por una educación concientizadora eran reiteradamente impugnados y tildados por parte de la nueva izquierda pedagógica de idealistas o ingenuos al no centrarse en la lucha de clases. Pero, si la propia cita del autor no era suficiente para alertar al lector/a, el brevísimo comentario remataba: "El debate está abierto sobre la teoría de la educación que, al parecer, Freire está cuestionando más rápidamente que sus epígonos".

El tratamiento crítico a P. Freire también se registró en distintos artículos, aunque sin una adjetivación tan elocuente. Existen varios escritos en esta línea, pero el trabajo de Guillermo García es uno de los más ilustrativos ${ }^{47}$. En el n ${ }^{\circ} 31$ (agosto-septiembre de 1973) el autor reflexionó sobre la pedagogía y su papel en los procesos revolucionarios que se venían gestando en "nuestras sociedades dependientes". Una de sus responsabilidades

\footnotetext{
45 "Editorial", Los Libros, n' 21, agosto de 1971, 3.

46 De Diego, op. cit, 36.

${ }^{47}$ Guillermo García, "Pedagogía y revolución”, Los Libros, n’ 31, agosto-septiembre de 1972, 20-22. Otros artículos que contuvieron críticas a los planteos de P. Freire en LL fueron: Leandro Leiva "Argentina 1973: movimiento docente", Los Libros, no 32, octubre-noviembre de 1973, 18-20; Carlos Mallo, "Educación popular ¿Concientización o práctica revolucionaria?”, Los Libros, n 38, noviembre-diciembre de 1974, 2729; Carlos Mallo, "Paulo Freire y la pedagogía de la concientización", Los Libros, n 40, marzo-abril de $1975,17-23$.
} 
residía en "efectuar una acción de esclarecimiento y difusión ideológica" esta acción de propaganda ideológica, en su interior, no era revolucionaria sino que dependía del marco histórico. En ese sentido consideraba "confusos" ciertos planteos de P. Freire $^{49}$. El hecho de insistir en evitar toda acción pedagógica en términos de "propaganda" o "sloganización" - dado que en sí mismos eran recursos reaccionarios-, conducía a una concepción "pedagogista de la revolución". Esto quiere decir que se imponían criterios pedagógicos a una teoría-acción revolucionaria cuando su definición debía pasar o considerar otras instancias -económicas, políticas, etc.- que desbordaban "la presunta normatividad pedagógica".

G. García le endilgaba un sesgo ingenuo a P. Freire que se asentaba en la crítica althusseriana al humanismo. Para el filósofo francés, el humanismo era tributario de una ideología burguesa, e inscribía al hombre en el principio de toda teoría, desgajándolo de sus condiciones reales. La lucha de clases se opacaba en pos de una teoría basada en algún ideal de tipo moral, religioso o filosófico sobre el hombre. Lejos de cualquier tentativa humanista, G. García reclamaba una crítica pedagógica atada a las condiciones materiales de existencia, a la contienda clasista.

Ilustrativo de la incompatibilidad entre P. Freire y L. Althusser resulta la selección bibliográfica sobre la cuestión educativa incluida en el $\mathrm{n}^{\mathrm{o}} 31$, preparada por Horacio Cuello y Fernando Mateo. Allí se agrupaba la bibliografía en tres ítems: a) educación y política educacional; b) educación y economía; c) educación e ideología. Dentro de cada ítem se distinguía entre producciones ligadas a una concepción y una ejecución orientada a la conservación y reproducción del sistema y aquellas animadas por una perspectiva crítica. Dentro del tercer ítem, y como parte de las producciones asociadas a la conservación, se ubicaba a Pedagogía del Oprimido, mientras que "Ideología y aparatos ideológicos" se integraba a la perspectiva educativa crítica.

En este marco, no llama la atención que la apelación pedagógica de Gramsci en $L L$ haya permanecido desapegada del legado de P. Freire y se encuentre en tensión o articulación con la obra althusseriana. Para asir esta clave de lectura del comunista italiano, es preciso distanciarse de un consenso historiográfico, ahondando la interesante veta abierta por Starcenbaum $^{50}$ al reflexionar sobre la experiencia del colectivo de intelectuales argentinos nucleados en la revista Pasado y Presente. El consenso historiográfico supone que el auge del marxismo estructuralista en la década del 60 contrajo un conocimiento de Gramsci a través de la obra de L. Althusser y, por tanto, de una forma difusa, siendo un obstáculo para su recepción creativa y productiva. Esta tesis, compartida en nuestro país por algunos autores $^{51}$, también se encuentra en los estudios sobre la recepción de Gramsci en América

\footnotetext{
${ }^{48}$ García, op. cit, 20.

${ }^{49}$ En La educación como práctica de la libertad y Pedagogía del oprimido, ambos editados por Siglo XXI.

${ }^{50}$ Op. cit.

${ }^{51}$ En su investigación del colectivo Pasado y Presente, Raúl Burgos, Los gramscianos argentinos, Bs. As., siglo XXI, 2004, 191, califica la identidad althusseriana en términos de "contingencia", mientras Horacio Crespo, "En torno a Cuadernos de Pasado y Presente, 1968-1983", Claudia Hilb (comp.), El político y el científico. Ensayos en homenaje a Juan Carlos Portantiero, Bs. As., Siglo XXI, 2009, 193, habla de la
} 
Latina en las décadas del 60 y 70 como apuntó Starcenbaum ${ }^{52}$ : Nogueira (1988) plantea que la obra de Gramsci se encontró con una intelectualidad inundada de estructuralismo y del efecto Althusser ${ }^{53}$; Coutinho sostiene que el privilegio alcanzado por la supuestamente radical obra althusseriana relegó la producción gramsciana ${ }^{54}$; Córdova (1991) apunta como lamentable el hecho de que la figura de Gramsci fuera conocida a través de las críticas althusserianas $^{55}$; Massardo considera que la legitimidad alcanzada por el althusserianismo conllevó una postergación de la recepción de Gramsci, impidiendo una valoración de la productividad de su obra ${ }^{56}$. En el terreno educativo, Torres y Morrow han señalado la lectura problemática de Gramsci por parte del estructuralismo althusseriano en la década del 60, que tildó su obra de humanista e historicista ${ }^{57}$. Seguramente, el marcado tono antialthusseriano de algunas de estas interpretaciones esté atravesado por el balance crítico de la izquierda latinoamericana respecto al derrotero teórico de los años 60 y 70 . Por el contrario, el gramscismo descubierto entrados los 70, vendría a dar respuesta a cuestiones obturadas por el althusserianismo.

\section{Una exégesis de Gramsci en $L L$ desde el ángulo pedagógico}

Aunque Gramsci fue evocado en general y, en particular, en el plano educativo a lo largo de la publicación, un caso emblemático aconteció a través de la traducción de un artículo de Christine Buci-Glucksmann, "Gramsci y la cuestión escolar" ${ }^{\text {"58 }}$ en el $\mathrm{n}^{\circ} 32$ (octubrenoviembre de 1973), abocado al ámbito pedagógico. No sería procedente asumir el artículo como una oficial expresión del tratamiento de Gramsci por parte de $L L$, pero es cierto que resultó el único manuscrito consagrado al pensamiento gramsciano por parte de la publicación, lo que le asigna relevancia.

“contaminación althusseriana” de J. Aricó al fundamentar el propósito de los Cuadernos de Pasado y Presente. Ver Marcelo Starcenbuam, "Más allá del principio de exclusión: Gramsci y Althusser en Pasado y Presente", Prismas, $\mathrm{n}^{\circ}$ 2, 2014, 199-203. Estas interpretaciones son solidarias del canónico estudio de Terán, op. cit., 105 que al analizar la primera época de la revista Pasado y presente (1963-1965) le endilga un marxismo humanista y, explícitamente, lo aleja de la posterior propuesta althusseriana sobre el marxismo.

${ }^{5}$ Op. cit., 36-7.

${ }^{53}$ Marcos Aurélio Nogueira, "Gramsci, a questão democrática e a esquerda no Brasil", en Carlos Nelson Coutinho y Marcos Aurélio Nogueira (org), Gramsci e a América Latina, Rio de Janeiro, Paz e Terra, 1988, $130-152$.

54 Carlos Nelson Coutinho, "Brasil y Gramsci: variadas lecturas de un pensamiento". Nueva Sociedad. Democracia y política en América Latina, n 115, 1991, 104-113.

${ }^{55}$ Arnaldo Córdova, "Gramsci y la izquierda mexicana". Nueva Sociedad. Democracia y política en América Latina, $\mathrm{n}^{\circ} 115,1991,160-63$.

56 Jaime Massardo, "Gramsci in America Latina. Questioni di ordine teorico e político", Alberto Burgio y Antonio A. Santucci, Gramsci e la rivoluzione in Occidente. Roma, Eds. Riuniti, 1990, 324-355.

${ }^{57}$ Carlos Torres y Raymond Morrow, Las Teorías de la Reproducción Social y Cultural. Manual Crítico. Madrid, Editorial Popular, 2002.

${ }^{58}$ Christine Buci-Glucksmann, “Gramsci y la cuestión escolar”, Los Libros, $\mathrm{n}^{\circ}$ 32, octubre-noviembre de 1973, 4-8. El artículo había aparecido en Literature/science/idéologique, n 3-4, 1972, 4-10. 
Vale puntualizar que Gramsci no fue en ningún momento presentado en $L L$, ni existieron reseñas de sus libros. Tampoco se registraron discrepancias o rechazos a su obra. Más bien existieron algunos elocuentes reconocimientos por parte de los animadores principales. R. Piglia aseguraba: "La publicación de los tres tomos de escritos de B. Brecht sobre arte y literatura es sin duda el acontecimiento más importante de la estética marxista desde la aparición de los Cuadernos de Antonio Gramsci",59.

¿Por qué $L L$ incluyó este artículo de C. Buci-Glucksmann? ¿Cuáles fueron sus móviles para traducirlo? El texto condensaba los dos ejes del proyecto crítico-pedagógico de la revista: a) desmenuzar los mecanismos de la dominación ideológica escolar; b) fundamentar una crítica educativa prospectiva. Asimismo, el manuscrito presentaba una relación tensa con el legado althusseriano y, específicamente, su interpretación de la obra gramsciana sin caer, por ello, en abordajes de corte voluntaristas o idealistas. El escrito de C. Buci-Glucksmann incluido en $L L$ fue contemporáneo a un libro de la autora que realizó entre 1973-1974 y que fue publicado en 1975 en Francia donde abordó el conjunto de la producción gramsciana $(\text { Idem })^{60}$. Además de trabajar con la edición cronológica e íntegra de los Cuadernos - que conoció de primera mano en sus visitas al Instituto Gramsci en Roma- contempló los escritos gramscianos precarcelarios. Una ardua tarea de exégesis de casi 500 páginas. Su artículo, incluido en $L L$, sólo gana inteligibilidad al situarlo en este proyecto ambicioso de la autora.

C. Buci-Glucksmann, militante del Partido Comunista Francés (al que ingresó en 1966), permaneció bajo las influencias de su maestro, L. Althusser. En su lectura de Gramsci, se registraban los propósitos del althusserianismo: volver a las fuentes del marxismo, distanciándose tanto de las versiones mecanicistas como de las nuevas tentativas revisionistas de cuño humanista o historicista. Además, la filósofa francesa se apoyó en los códigos althusserianos para leer a Gramsci, aunque, a partir de la autocrítica de su maestro (ante todo, en 1974 cuando se publicó en París Éléments d'autocritique), se diferenció de L. Althusser e inauguró un nuevo camino. No obstante, esta distancia fue sólo parcial. Reiteradamente, el legado althusseriano animó su exégesis sobre el revolucionario sardo. Como había sugerido L. Althusser y, luego, desarrolló Nicos Poulantzas, C. BuciGlucksmann emprendió una lectura sintomática de Gramsci. Citaba a su maestro, cuando sostenía que "Leer es practicar una problemática"61.

\footnotetext{
${ }^{59}$ Ricardo Piglia, "Mao Tse-Tung Práctica estética y lucha de clases", Los Libros, n 25, marzo de 1972, 25.

${ }^{60}$ Otro escrito de la autora contemporáneo al artículo y homogéneo en su fundamentación de la lectura de Gramsci, se encuentra en su introducción al libro de Lucio Colletti, From Rousseau to Lenin: Studies in Ideology and Society, London, New Left Books, 1972, 3-10, consagrado a la discusión del historicismo y de su interpretación por L. Althusser. También en Christine Buci-Glucksmann, "Mode de production, Formation économique et sociale, Théorie de la Transition. A propos de Lénine", La Pensée, $\mathrm{n}^{\circ}$ 159, septiembre-octubre de 1971, 50-58, la autora reivindicó el andamiaje y códigos althusserianos para trabajar con el legado marxista.

${ }^{61}$ Buci-Glucksmann, op. cit., 1978 [1975], 29.
} 
La filósofa francesa inscribía al revolucionario sardo en la problemática del Estado ${ }^{62}$. Desde esa perspectiva indagó en la originalidad gramsciana y en sus diferentes conceptos. Gramsci, anclado en la tradición marxista-leninista, había introducido una novedad a través de su concepto de Estado ampliado o pleno y operado un desdoblamiento del concepto de hegemonía, reparando ya no sólo en la constitución de la clase proletaria sino también en el análisis del Estado a través de la noción de aparatos de hegemonía. Mediante la problemática señalada, la autora, como fiel althusseriana, albergaba vastas expectativas. Del abordaje del tratamiento gramsciano del Estado se derivaban cuestiones de índole filosóficas. Su teoría del aparato hegemónico se traducía en una teoría del aparato de hegemonía filosófico $(A H F) \mathrm{y}$, por tanto, establecía una nueva relación entre filosofía, cultura y política, esto es, una gnoseología de la política. En resumidas cuentas, C. BuciGlucksmann, siguiendo una lectura sintomática, rastreaba la filosofía gramsciana no en sus enunciados filosóficos explícitos, sino en su abordaje del Estado. Subyacía aquí, en su política, una filosofía implícita que cualquier lectura literal evadía y sólo era asequible a través del desplazamiento que operaba la inscripción de la problemática del Estado en la obra gramsciana. La política realizaba a la filosofía, le otorgaba un contenido real, material. La autora daba cuenta de esta conjunción de la política y la filosofía -que denominaba gnoseología de la política - tanto al analizar la filosofía en su inscripción superestructural teoría del aparato de hegemonía filosófico-, como al derivar conceptos a partir de la nueva estrategia política gramsciana -la guerra de posiciones- para los países capitalistas avanzados. Con su teoría del AHF y su gnoseología de la política, bregaba por elucidar los elementos de una filosofía materialista en Gramsci y, así, ajustar cuentas con la dialéctica idealista $^{63}$. Después de todo, proseguía el combate de L. Althusser contra la hegelianización de Gramsci.

Esta lectura sintomática de Gramsci, tensionó a L. Althusser en varios niveles. C. BuciGlucksmann emprendió una nueva aproximación al comunista italiano, distante de la realizada por su maestro. Básicamente, la crítica al historicismo gramsciano por el althusserianismo, partiendo de una matriz común a todo historicismo -de J.P. Sartre a G. Lukács-, a pesar de que había arrojado luz sobre la presencia hegeliana en el marxismo, era insostenible e inaplicable a Gramsci. La autora demostró que, atendiendo al abordaje gramsciano del Estado, se desprendía una filosofía que lejos estaba de abrevar en el historicismo hegeliano o crociano. El mote historicista endosado por L. Althusser a G. Lukács o K. Korsch no se ajustaba a Gramsci. El revolucionario sardo había emprendido una delimitación tanto del mecanicismo como del revisionismo idealista ${ }^{64}$. Si para L. Althusser debía desgajarse la filosofía historicista gramsciana, para la autora, la filosofía gramsciana tenía un filón, no historicista, sino más bien materialista, tangible sólo a través de la problemática del Estado. Esta línea inexplorada por L. Althusser fue desarrollada por C. Buci-Glucksmann. Aseveró que la ampliación del Estado a través de los aparatos de

\footnotetext{
${ }^{62}$ También en Buci-Glucksmann, op. cit., 1973, 5. Aquí la autora centró su interpretación de la obra de Gramsci a partir de la refundación que éste efectuó del concepto de Estado.

${ }^{63}$ Buci-Glucksmann, op. cit., 1978 [1975], 14-29, 404-419.

${ }^{64}$ Op. cit., 1978 [1975], 205-6, 278.
} 
hegemonía suponía atender a contradicciones secundarias o específicas. Así un modelo expresivo del todo social de origen hegeliano, conforme a la matriz teórica de todo historicismo -tal y como proponía L. Althusser en Para leer el Capital-, no aplicaba a Gramsci. Según la autora, la unidad social en el comunista italiano no se resumía en la praxis sino que presentaba momentos desiguales, heterogéneos. Asimismo, intentó desandar un punto cardinal de la crítica althusseriana: la acusación de historicista a Gramsci que se asentaba, entre otros puntos, en su homologación de ciencia o filosofía con ideología. En otras palabras, la comprensión de Gramsci de la ciencia como superestructura desechaba, según L. Althusser, la tarea teórica o la reducía a un mero empirismo - a una contrastación constante con la práctica, con las cambiantes coyunturas-. Anclaba los conceptos marxistas, los conceptos científicos en la situación histórica, al tiempo que identificaba filosofía e historia. Básicamente, C. Buci-Glucksmann respondió a esta crítica trabajando el filón materialista de la filosofía de Gramsci e interpretando la tesis gramsciana de la "ciencia como superestructura", no en términos de un subjetivismo de clase - del tipo ciencia burguesa/ciencia proletaria-, sino como parte de la búsqueda del conocimiento objetivo.

Igualmente, en este camino original, la filósofa francesa reparó reiteradamente en preceptos althusserianos. Trabajó la ligazón de la filosofía con la lucha de clases. El estatuto de la filosofía gramsciana se dirimía en la disputa clasista, por lo que le había demandado ajustes perpetuos al revolucionario sardo. De ahí que la autora distinguió entre historización legítima e historicismo. Era preciso situar a Gramsci en la historia, para desideologizar los análisis y medir mejor la validez real de sus conceptos. En otras palabras, se requería una historización legítima, pero que jamás debía derivar en un historicismo sustituyente de la tarea teórica gramsciana ${ }^{65}$. En última instancia, como su maestro, jerarquizaba y sostenía la autonomía de la práctica teórica. Además, la autora se apoyaba en aquellas intuiciones productivas divisadas por L. Althusser en el comunista italiano, entre ellas las relaciones entre filosofía y política, la ampliación del Estado, el carácter material de la ideología. Débil en el terreno filosófico, en el plano del materialismo histórico Gramsci presentaba apuntes dignos de consideración, según el filósofo francés. C. Buci-Glucksmann ${ }^{66}$ profundizó y enriqueció estas intuiciones registradas por su maestro, pero en lugar de escindirlas del ámbito filosófico, las trabajó como parte de la filosofía materialista gramsciana a la luz de la problemática del Estado ${ }^{67}$. En definitiva, mediante el empleo del método de lectura althusseriano y la incorporación de algunas de las observaciones de su maestro, pero distanciándose de otras, la autora emprendió una renovada lectura de la obra del comunista italiano.

La introducción de un artículo de C. Buci-Glucksmann por $L L$, además de expresar la familiaridad de la publicación con elaboraciones francesas, guardaba un tono coherente con la revista, al postular una clave de lectura de Gramsci alejada del humanismo. Esta afinidad, este registro compartido fue un nivel que justificó la opción por el artículo. Hay

\footnotetext{
${ }^{65}$ Buci-Glucksmann, op. cit, 1973, 4; Buci-Glucksmann, op. cit., 1978 [1975], 24

${ }^{66}$ Buci-Glucksmann, op. cit., 1978 [1975], 417.

67 Op. cit., 1978 [1975], 91.
} 
otro pegado a éste que también contribuyó y, presumiblemente, resultó más palpable para los protagonistas de la publicación: el manuscrito de C. Buci-Glucksmann respondía orgánicamente al proyecto crítico de $L L$ en el plano pedagógico. En principio, la autora ofrecía una interpretación materialista de Gramsci y, específicamente, de su tratamiento de la cultura. El comunista italiano, en la versión de C. Buci-Glucksmann, no abogaba por un culturalismo idealista que desplazaría al marxismo-leninismo del terreno de la lucha de clases hacia la cultura, sino que abordaba la cultura en su encarnación conflictiva y material, en su enraizamiento en los aparatos hegemónicos.

Además de la más que evidente distancia con el economicismo, esta lectura de Gramsci coincidía con el proyecto de $L L$, "Una crítica política de la cultura", y con su demarcación de las tentativas humanistas, manifestadas por el nacionalismo popular. Éstas jerarquizaban el discurso fanoniano o freiriano y, por tanto, las posibilidades de transformación a través de la voluntad. Para C. Buci-Glucksmann, como para $L L$, la disputa cultural debía centrarse, no en la voluntad, sino en la lucha de clases y, desde esa posición, asir la dominación, las opciones populares y el papel de los intelectuales. Específicamente, se trataba de aprehender la ampliación del Estado y la dinámica de los aparatos culturales, tema tan reiterado en $L L$, en base al enfrentamiento clasista. De hecho, para C. BuciGlucksmann la ocultación del concepto de aparatos de hegemonía en la exégesis sobre Gramsci, había conducido a una preeminencia de lo ideológico sobre el análisis de las superestructuras, a una preeminencia de la problemática del bloque histórico sobre la de relaciones de fuerza y del Estado, en suma, a una "desviación cultural idealista" en la interpretación del comunista italiano ${ }^{68}$.

La noción gramsciana de aparatos hegemónicos empleada por la autora, contribuía a una de las aristas del proyecto de $L L$ : evidenciar los mecanismos ideológicos de dominación arraigados materialmente en los aparatos culturales, entre ellos, el educativo. C. BuciGlucksmann trabajaba sobre la ampliación del Estado divisada por L. Althusser en Gramsci. Tanto los aparatos de hegemonía como los Aparatos Ideológicos de Estado (AIE) evidenciaban las formas de persuasión, de construcción de consenso de las clases dominantes. Ubicaban, pues, el lugar, las funciones y las eficacias diferenciales de los aparatos en el conjunto social.

Sin embargo, esta crítica de la cultura reclamaba, para la publicación, otro costado: una crítica prospectiva. El artículo de $\mathrm{C}$. Buci-Glucksmann avanzaba y cuestionaba el legado althusseriano y poulantziano sobre Gramsci en un punto sensible: el atravesamiento de la lucha de clases en el Estado producía grietas. El aparato de hegemonía gramsciano no se reducía a los $\mathrm{AIE}^{69}$. Éstos últimos, y aquí la autora se apoyaba en la autocrítica de L. Althusser, resultaban un obstáculo cuando se quería determinar políticamente los nexos entre la base, la superestructura y la lucha de clases. Es decir, el concepto de reproducción se mostraba insuficiente para asegurar la riqueza del Estado ampliado gramsciano al escindirlo de la concreta contienda clasista.

\footnotetext{
${ }^{68}$ Buci-Glucksmann, op. cit., 1978 [1975], 38.

${ }^{69}$ Buci-Glucksmann, op. cit, 1973, 7.
} 
Para la autora, las parejas teóricas y metodológicas de Gramsci eran bipolares: no había una teoría de la hegemonía sin una teoría de la crisis de hegemonía; no había una análisis de la integración de las clases subalternas por una clase dominante sin la teoría de los modos de autonomización de los sectores populares; no había una ampliación del concepto de Estado sin la redefinición de una perspectiva estratégica nueva -la guerra de posicionesque posibilitaba a las clases subalternas luchar por un nuevo Estado. De ahí el error de N. Poulantzas: reducir la utilización del concepto de hegemonía solamente a las prácticas de la clase dominante, convirtiendo de este modo la hegemonía en sinónimo de ideología dominante. Al conjugar los aparatos de hegemonía con la problemática del Estado gramsciano y la estructuración de una estrategia de nuevo tipo para los países capitalistas avanzados, C. Buci-Glucksmann concluía que al consenso dominante le continuaba, en Gramsci, una impugnación de las clases subalternas y, por tanto, una disputa en los aparatos culturales. Los efectos de la hegemonía devenían más que contradictorios. En su artículo, incluido en $L L$, marcaba las diferencias entre el Estado ampliado gramsciano y los AIE althusserianos: "Lo que interesa a Gramsci es la dialéctica que permite que una 'clase subalterna' se convierta en hegemónica. De allí la profundización de conceptos como el de crisis y del modo mismo según el cual se organiza la nueva hegemonía (teoría del partido y 'reforma intelectual y moral') en sus relaciones con la clase y el conjunto de la sociedad" ${ }^{\text {"70 }}$.

Por ello, C. Buci-Glucksmann colocó como nudo del pensamiento gramsciano el carácter pedagógico de cada relación hegemónica. Expresada de manera neurálgica en el aparato escolar, este vínculo no se reducía, sin embargo, a las relaciones específicamente escolares sino que atravesaba al conjunto social. La impronta vincular, pedagógica, de la hegemonía permitía asir tanto la dominación como las impugnaciones en los aparatos hegemónicos. De allí que, en su artículo, la autora reparó, siguiendo a Gramsci, en las opciones subalternas a la hegemonía burguesa.

La propia editorial del $\mathrm{n}^{\circ} 32$, se hacía eco de este asunto cardinal: "Toda relación de hegemonía es, a la vez y por su función pedagógica", aseguraba ${ }^{71}$. La jerarquía de este tema gramsciano se explicaba por la doble respuesta que el artículo de C. Buci-Glucksmann ofrecía al proyecto crítico de $L L$. En otras palabras, además de analizar la dominación en las instituciones burguesas, fundamentaba una arista principal para la publicación: la lucha específica en los aparatos culturales, a fin de desagregar todas las reservas organizativas de la clase dominante. Asimismo, la perspectiva de la autora fundamentaba la crisis del sistema educativo y, por tanto, las bases de la crítica prospectiva. LL solía aludir a la crisis orgánica o hegemónica que atravesaban las instituciones educativas como parte de una crisis social más vasta, jerarquizando una instancia mediadora: la ideología. Espacio propicio, en consecuencia, para categorías gramscianas atentas al papel de la ideología y su arraigo social, como "crisis orgánica". El editorial del $n^{\circ} 31$ comenzaba de la siguiente manera: "La 'cuestión' educativa. Crisis es, sin duda, la palabra que aparece casi inmediatamente si se quiere definir hoy el problema de la escuela en la Argentina"72.

\footnotetext{
${ }^{70}$ Buci-Glucksmann, op. cit., 1973, 7.

71 "Editorial", Los Libros, n 32, Octubre-noviembre de 1973, p. 3.

72 "Editorial”, Los Libros, n 31, agosto-septiembre de 1973, p.3.
} 
La noción de "crisis orgánica", extendida y diseminada en las páginas de la publicación, tenía en el artículo de C. Buci-Glucksmann un tratamiento particular, denso. La autora profundizaba en las características de la "crisis orgánica" observadas por Gramsci y enfatizaba que no se reducía al ámbito educativo, sino que era una crisis global, una crisis de hegemonía de la clase dirigente, una crisis que comprendía al Estado y a sus aparatos de hegemonía -al Estado ampliado-, a la capacidad de dirección ideológica y cultural de la clase dominante ${ }^{73}$. Es sabido que bajo la noción de crisis orgánica, se jugaba un dilema traumático en Gramsci: o comenzaba a operar un poder apoyado en fuerzas ilegales y cómplices de la burguesía y se preparaba una forma extrema de coerción estatal, o bien, se oponía una fuerza popular organizada y estratégica.

Desde ya, la autora, como $L L$, bregaba por la segunda opción. Así, y nuevamente emergía la crítica prospectiva, C. Buci-Glucksmann recopilaba las reflexiones de Gramsci como solución ante la crisis. Por un lado, y en línea con M. Manacorda, sugería en su artículo dos alternativas específicamente educativas: la alternativa escolar y la alternativa pedagógica. La primera suponía el acceso de la clase obrera a una escuela única, general, desinteresada, lejos pues de la mera especialización que proponía la burguesía. La segunda, indicaba una pedagogía de la promoción, una pedagogía activa, pero que no debía desembocar en un mero espontaneísmo. Instaba a un abordaje agudo y productivo de la cultura subalterna que encerraba tanto elementos críticos como elementos importados de las ideologías dominantes. A fin de valorar la cultura popular y tejer un vínculo democrático, no paternalista, la autora recordaba la III $^{\mathrm{a}}$ tesis sobre Feuerbach de Marx, tantas veces aludida por Gramsci: el educador debe ser educado.

La lucha de clases atravesaba al ejercicio crítico de la autora, por lo que cualquier alternativa postulada no podía afincarse sólo en el plano educativo o escolar. La suerte que corriesen las soluciones propuestas en el ámbito educativo era indisoluble de la lucha global por la constitución del nuevo bloque histórico. Con ciertos aires maoístas ${ }^{74}$ afines a los principales animadores de $L L$, C. Buci-Glucksmann se centraba en Gramsci, y especialmente en sus consideraciones sobre la cuestión meridional, para bregar por la conformación de una alianza entre el proletariado y la gran masa campesina, capaz de romper el bloque agrario conducido por los propietarios terratenientes y sus intelectuales.

La inclusión del artículo de C. Buci-Glucksmann, por tanto, no resultó fortuita. Respondía de forma orgánica y coherente a una serie de singularidades de $L L$. Al diálogo con el legado althusseriano y a la demarcación con las tentativas humanistas, le seguía un Gramsci capaz tanto de criticar la materialidad del dominio escolar como de sugerir vetas de transformación social y educativa.

\footnotetext{
${ }^{73}$ Buci-Glucksmann, op. cit., 1973, 7.

${ }^{74}$ Buci-Glucksmann, op. cit., 1973, 5.
} 


\section{Conclusión}

Se ha intentado dar cuenta del derrotero de $L L$, atendiendo al doble proceso que la animó: la modernización cultural y la radicalización política. Afirmando la persistencia de la crítica cultural en la segunda etapa de la revista, se indagó en su proyecto crítico pedagógico signado por develar los mecanismos ideológicos del aparato escolar y estructurar una crítica prospectiva. Aunque en distintas oportunidades conceptos gramscianos fueron esgrimidos en esta línea, la traducción del artículo de la filósofa francesa C. Buci-Glucksmann le permitió a la publicación fundamentar su crítica pedagógica a través de una lectura del acervo gramsciano desapegado de las vertientes humanistas. Lejos de una mera oposición entre el althusserianismo y el gramscismo, la autora ofrecía zonas de compatibilidad e intercambio coherentes con la tonalidad del proyecto crítico-pedagógico de $L L$. De todas maneras, permanece pendiente un estudio capaz de desmenuzar los múltiples usos de Gramsci por parte de la revista, siendo el presente artículo tan sólo una contribución.

Sabido resulta que a partir de los años 80 , Gramsci se volverá gravitante en la teoría educativa. Sin embargo, es preciso advertir que hacia principios de los 70, el revolucionario sardo ya animaba a la pedagogía crítica. El althusserianismo no fue apropiado linealmente para pensar el tópico educativo por parte de la nueva izquierda en los años 60/70 sino que estuvo atravesado por ciertas incomodidades. En el caso de $L L$, el legado gramsciano permitió desandar una de esas incomodidades a través de fundamentar una veta suturada por el filósofo francés: la intervención político-pedagógica. De alguna manera si L. Althusser permitía limar los costados subjetivistas y voluntaristas de Gramsci, la obra gramsciana fundamentaba la crítica prospectiva.

Recibido: 8 abril 2016 Aceptado: 6 junio 2016

\section{Bibliografía}

AA.VV, "Los Libros: la construcción de un texto posible, entre el Cordobazo y el Golpe". El Matadero. Revista crítica de literatura argentina, $\mathrm{n}^{\circ}$ 4, 2005, 241-260.

Adrián Celentano, "Insurrección obrera y compromiso intelectual", Archivos de historia del movimiento obrero y la izquierda, $\mathrm{n}^{\circ} 4,2014,53-76$.

Adriana Petra, "El momento peninsular. La cultura italiana de posguerra y los intelectuales comunistas argentinos", Izquierdas, $\mathrm{n}^{\circ}$ 8, 2010, 1-25.

Anna Popovitch, "La recepción de Althusser por la Nueva Izquierda Argentina: el caso de Los libros (1969-1976)". Granados García, A. (coord.), Las revistas en la historia intelectual de América Latina. México, Universidad Autónoma Metropolitana / J. Pablos, 2012, 127-143

Arnaldo Córdova, "Gramsci y la izquierda mexicana”, Nueva Sociedad. Democracia y política en América Latina, n 115, 1991, 160-63. 
Sebastián Gómez, El derrotero de Los Libros (1969-1976) y su crítica pedagógica. La interpretación educativa de Antonio Gramsci a través de Christine Buci-Glucksmann, Izquierdas 28: 292-314, Julio 2016

Beatriz Sarlo y Carlos Altamirano, Ensayos argentinos. De Sarmiento a la vanguardia, Bs. As, Centro Editor, 1983.

Beatriz Sarlo, El rol de las revistas culturales, Bs. As., Facultad de Filosofía y Letras Universidad de Buenos Aires, 1992

Carlos Nelson Coutinho, "Brasil y Gramsci: variadas lecturas de un pensamiento", Nueva Sociedad. Democracia y política en América Latina, $\mathrm{n}^{\circ}$ 115, 1991, 104-113.

Carlos Torres y Raymond Morrow, Las Teorías de la Reproducción Social y Cultural. Manual Crítico. Madrid, Editorial Popular, 2002.

Christine Buci Glucksamnn, Gramsci y El Estado (Hacia una teoría materialista de la Filosofía), México, Siglo XXI, 1978 [1975].

Emilio De Ipola, Althusser, el infinito adiós, Bs. As., Siglo XXI, 2007.

Eva Fontdevila y Adrián Pulleiro, "Los Libros. De la modernización a la partidización", Revista Zigurat, n5, 2004, 168-173.

Hans-Robert, Jauss, Pour une esthétique de la réception, París, Gallimard, 1978.

Horacio Crespo, "En torno a Cuadernos de Pasado y Presente, 1968-1983", Claudia Hilb (comp.), El político y el científico. Ensayos en homenaje a Juan Carlos Portantiero, Bs. As., Siglo XXI, 2009.

Horacio Tarcus, Marx en la Argentina. Bs. As., Siglo XXI, 2007.

Jaime Massardo, "Gramsci in America Latina. Questioni di ordine teorico e político", Alberto Burgio y Antonio A. Santucci, Gramsci e la rivoluzione in Occidente. Roma, Eds. Riuniti, 1990, 324-355.

Jorge Panesi, "La crítica argentina y el discurso de la dependencia", Panesi, J. Críticas. Bs. As, Norma, 2000 [1985], 17-48.

José Luis De Diego, ¿Quién de nosotros escribirá el Facundo? Intelectuales y escritores en Argentina (1970 - 1986), La Plata, Al Margen, 2007.

Marcelo Starcenbaum, (2011), "El marxismo incómodo: Althusser en la experiencia de

Pasado y Presente", Izquierdas, n 11, 2011, 35-53.

Marcelo Starcenbuam, "Más allá del principio de exclusión: Gramsci y Althusser en Pasado y Presente", Prismas, n² 2, 2014, 199-203.

Marcos Aurélio Nogueira, "Gramsci, a questão democrática e a esquerda no Brasil", Carlos

Nelson Coutinho y Marcos Aurélio Nogueira (org), Gramsci e a América Latina, Paz e Terra, Rio de Janeiro, 1988, 130-152.

Oscar Terán, Nuestros años sesentas. La formación de la nueva izquierda intelectual en la Argentina, 1956-1966, Bs. As., Puntosur, 1991.

Patricia Somoza y Elena Vinelli, "Para una historia de Los Libros", Los Libros: edición facsimilar. Bs. As, Biblioteca nacional, 2011, 9-19.

Raúl Burgos, Los gramscianos argentinos, Bs. As., siglo XXI, 2004. 